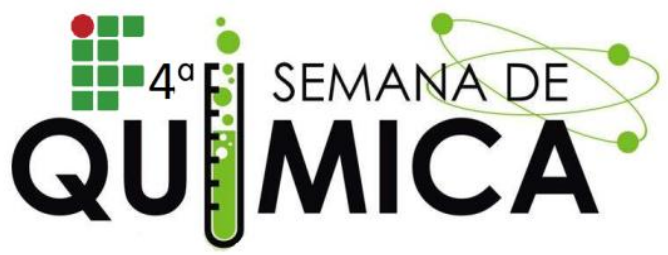

\section{ESTUDO E ANÁLISE FÍSICO-QUÍMICA DA ÁGUA UTILIZADA EM UM LAVA-JATO DA REGIÃO AGRESTE}

Autores: MENDES, M.M., NASCIMENTO, R.P (IFRN), SOUZA, D.

S. (ORIENTADORA)

Palavras Chave: água, efluentes, lava a jato 3.

\section{INTRODUÇÃO}

Tendo em vista a escassez da água, é interessante um acompanhamento das formas de utilização da mesma visando seu uso racional. Inúmeras atividades realizadas com essa substância tem um aproveitamento baixo e um desperdício alto, uma delas pode ser exemplificada nas atividades realizadas em um lava jato, nesse serviço desperdiça muita água que pode ser reutilizada com simples tratamento. Cada Lava jato simples consome, por dia, em média mil litros de água, sendo que muitos abusam do desperdício e utilizam produtos químicos que agridem o meio asfalto, e ganham as redes de água pluviais, que caem nos leitos d'água da cidade. Estes resíduos deveriam ser recolhidos duas vezes por semana através da limpeza das caixas e alocados em tambores para, posteriormente, ser transportado por empresas especializadas na destinação final. (PEREIRA, et. Al, 2009). METODOLOGIA

Materiais: Pipetas volumétricas; Erlenmeyers; Beckeres; Frasco para coleta da amostra; Termômetro; Proveta de $100 \mathrm{ml}$; Frasco lavador; Papel absorvente; Equipamentos: Medidor de $\mathrm{pH}$; Turbidímetro; Condutivímetro; Reagentes: Soluções padrões para condutivímetro; Soluções tampão 7/4;

Procedimento Experimental: Foi coletada a amostra de água na superfície em três pontos diferentes, em seguida foi observado o aspecto visualmente da aparência da amostra, após verificou- se o odor avaliado por olfato. Após foi feita a determinação da turbidez, foi necessário calibrar o equipamento com a solução padrão, em seguida fez-se a leitura das amostras em triplicata e anotou-se os valores dos resultados. Depois foi feita a determinação do $\mathrm{pH}$, calibrou-se o equipamento com as soluções padrões, e mediu-se o pH da amostra em triplicata, logo após anotou-se os resultados. A próxima análise feita foi a determinação de sólidos totais dissolvidos, calibrou-se o condutivímentro com a solução padrão, mediu-se o valor em ppm de STD na amostra, anotou-se os valores dos resultados.

\section{RESULTADOS E DISCUSSÕES}

Inicialmente foi coletada a água de três pontos diferentes do lava jato, a amostra A foi coletada no local onde aconteceu a lavagem do veículo, a amostra $B$ foi coletada em baixa da rampa onde fica o veículo para realizar a lavagem, a amostra $C$ foi coletada direto do esgoto do lava jato. Em seguida foi analisado o aspecto e o odor como mostra a tabela a seguir:

\begin{tabular}{|l|l|lr|}
\hline $\begin{array}{l}\text { Água do } \\
\text { lava jato }\end{array}$ & Aspecto & Odor \\
\hline Amostra A & $\begin{array}{l}\text { Muito } \\
\text { turva }\end{array}$ & $\begin{array}{l}\text { Cheiro de } \\
\text { borracha e } \\
\text { detergente }\end{array}$ \\
\hline Amostra B & $\begin{array}{l}\text { Menos } \\
\text { turva }\end{array}$ & $\begin{array}{l}\text { Cheiro forte de } \\
\text { graxa }\end{array}$ \\
\hline Amostra C & $\begin{array}{l}\text { Um pouco } \\
\text { límpida }\end{array}$ & $\begin{array}{l}\text { Cheiro } \\
\text { levemente de } \\
\text { graxa }\end{array}$ \\
\hline
\end{tabular}

Logo após mediu-se a temperatura da água, a amostra A com temperatura de $25^{\circ} \mathrm{C}$, amostra B com temperatura de $24^{\circ} \mathrm{C}$, amostra $\mathrm{C}$ com temperatura de $24^{\circ} \mathrm{C}$. Em seguida foi medida a

\begin{tabular}{|l|l|l|l|}
\hline $\begin{array}{l}\text { Valor de } \\
\text { referência } \\
\text { da } \\
\text { turbidez } \\
\text { CONAMA }\end{array}$ & $\begin{array}{l}\text { Amostra } \\
\text { Amostra B }\end{array}$ & Amostra C \\
\hline $\begin{array}{l}\text { Até 100 } \\
\text { NTU }\end{array}$ & 37,8 NTU & 38,1 NTU & 38,3 NTU \\
\hline
\end{tabular}


turbidez da água onde foram obtidos os seguintes resultados:

Valores dentro dos padrões de acordo com o Conselho Nacional do Meio Ambiente CONAMA. Com média obtida de 38,6 e desvio padrão de 0,25 . Em seguida fio analisado o $\mathrm{pH}$ da água como mostra a tabela a seguir:

\begin{tabular}{|c|l|l|l|}
\hline $\begin{array}{c}\text { Valores de } \\
\text { referência } \\
\text { do pH } \\
\text { CONAMA }\end{array}$ & Amostra A & $\begin{array}{c}\text { Amostra } \\
\text { B }\end{array}$ & $\begin{array}{c}\text { amostra } \\
\text { C }\end{array}$ \\
\hline 5,0 a 9,0 & 8,47 & 8,56 & 8,46 \\
\hline
\end{tabular}

Valores dentro dos padrões de acordo com o CONAMA. Com média de 8,49 e desvio padrão de 0,05. Logo após foi medida a condutividade e SDT da água onde obteve os seguintes valores:

STD

\begin{tabular}{|l|l|l|}
\hline Amostra A & Amostra B & Amostra C \\
\hline $105,3 \mathrm{ppm}$ & $105,3 \mathrm{ppm}$ & $105,4 \mathrm{ppm}$ \\
\hline
\end{tabular}

Com média de 105,3 e desvio padrão de 0,05

\section{Condutividade}

\begin{tabular}{|l|l|l|}
\hline Amostra A & Amostra B & Amostra C \\
\hline $208,2 \mathrm{uS}, \mathrm{cm}$ & $211,5 \mathrm{uS}, \mathrm{cm}$ & $211,4 \mathrm{uS}, \mathrm{cm}$ \\
\hline
\end{tabular}

Com média de 210,3 e desvio padrão de 1,53

\section{CONCLUSÃO}

Conclui-se que muitos lava jatos atuam de forma irregular na maioria das vezes por não terem orientação correta, em relação a análise da água observou-se que mesmo sem tratamento para o rejeito, neste lava-jato onde foram realizadas as análises, todos parâmetros estão de acordo com a resolução do Conselho Nacional do Meio Ambiente - CONAMA para lançamentos de efluentes.

\section{Referências}

Química industrial / Marcelo Gauto, Gilber Rosa.- Porto Alegre: Bookman, 2013.

Disponível em: http://www.partes.com.br/socioambiental/resi duossolidos.asp acesso em 09 de junho de 2016
Disponível

em:

http://www.mma.gov.br/estruturas/sedr proe cotur/ publicacao/140 publicacao0906200902 5910.pdf acessado em 07 de julho de 2016 Disponível

em;http://www.mma.gov.br/port/conama/res/ res11/propresol lanceflue 30e31mar11.pdf : acesso em 12 de Julho de 2016 Disponível 